\title{
PENGARUH PEMBERIAN MINUMAN KARBOHIDRAT ELEKTROLIT TERHADAP PRODUKTIVITAS KERJA PADA PEKERJA PEMBUATAN BATU BATA
}

\section{IKA NUR SAPUTRI ${ }^{1}$, FELIX KASIM ${ }^{2}$, IRMA NURIANTI ${ }^{2}$, DODI ARIF P SIAHAAN ${ }^{2}$}

\author{
Institut Kesehatan Medistra Lubuk Pakam \\ JIn. Jenderal Sudirman No. 38 Lubuk Pakam Kabupaten Deli Serdang \\ Sumatera Utara (20512) \\ e-mail :ikanursaputri@gmail.com
}

\begin{abstract}
Work productivity is influenced by many things, one of which depends on the availability of nutrients in the worker's body. In industrial workers, the lack of nutrient consumption that is often experienced is lack of fluids. Workers who worked in hot ambient temperatures for 10 days lost an average of 4.8 - 6 grams of sodium. However, lost body fluids cannot be replaced by simply drinking water during work. This research is a quantitative study with a quasy experimental study design with one group pretest-posttest design which aims to determine the effect of giving electrolyte carbohydrates on work productivity of brick-making workers. The population in this study were all brick-making workers in the drying section, a sample of 42 people who were taken using the total sampling technique. Data were analyzed using Paired Sample t-test with a $=0.05$. The results showed that there was an effect of giving electrolyte carbohydrate drinks on the work productivity of brick making workers ( $p$ value $=0.000$ ). Giving electrolyte carbohydrate drinks can increase energy intake and bind $\mathrm{Na}+$ to remain in the cells. Electrolyte carbohydrate drinks replace water and electrolytes lost through sweat during activity and replace carbohydrates used from liver and muscle reserves during activity. Therefore, the owner of the masonry factory is expected to be able to provide water and electrolyte carbohydrate drinks for workers so that workers' fluid needs are met, workers do not experience fatigue and eventually work productivity increases.
\end{abstract}

Keywords: Electrolyte Carbohydrate Drinks, Work Productivity

\section{PENDAHULUAN}

Produktivitas kerja sebuah konsep umum untuk memenuhi kebutuhan manusia dengan memproduksi barang dan jasa dengan menggunakan sumber daya yang terbatas. Selain itu juga ukuran efisiensi produktif, semakin tinggi produktivitas kerja para pekerja di suatu industri, maka keuntungan dan produktivitas industri tersebut juga akan meningkat (Yuniarsih, 2016).

Berdasarkan data Asian Productivity Organization, pada tahun 2015-2017, produktivitas tenaga kerja Asia tumbuh meningkat dari $4,8 \%$ pada tahun 2010 2015 menjadi rata-rata 5,0\% per tahun. Produktivitas tenaga kerja per-pekerja pada 2017 diukur sebagai Produk Domestik Bruto per pekerja dalam US 
dollars pada 2017. Singapura merupakan negara yang memiliki produktivitas tenaga kerja yang tertinggi, yaitu US\$ 1.423.000, sedangkan negara yang memiliki produktivitas terendah adalah Kamboja, yaitu US\$ 6.500. Indonesia berada di peringkat keempat untuk kawasan ASEAN dengan tingkat produktivitas per pekerja Indonesia pada tahun 2017 sekitar US\$21.000. Sementara pada tahun 2016 mengalami peningkatan produktivitas per pekerja di Indonesia (APO, 2019).

Kualitas dari hasil kerja setiap orang berbeda dan dipengaruhi oleh beberapa hal misalnya zat gizi yang tersedia ditubuh pekerja. Menurut Utami (2013) menyatakan bahwa jika mengkonsumsi zat gizi kurang dari standar minimum maka akan mempengaruhi kondisi kesehatan, aktivitas dan produktifitas kerja.

Pekerja industri sering mengalami kekurangan cairan melalui keringat dan akan menyebabkan dehidrasi jika cairan tersebut tidak diganti dan berdampak pada kemampuan fisik dan kognitif pekerja akan menurun. Selain itu, menurut Graham dalam Utami (2013), dehidrasi yang terjadi berhubungan dengan keseimbangan elektrolit yang berubah. Pekerja akan kehilangan sekitar 4.8 - 6 gram natrium yang setara dengan 12 - 15 gram garam ( $\mathrm{NaCL}$ ) jika bekerja pada suhu lingkungan panas selama 10 hari. Hal ini sesuai dengan hasil penelitian Brake DJ et al, (2013) bahwa $60 \%$ dehidrasi yang dialami dan setelah 10-12 jam berikutnya pada pekerja industri tambang di Australia tidak mengalami peningkatan. Penebang pohon di Afrika Selatan mengalami dehidrasi sebesar $44 \%$ (Biggs, 2011).

Desa Sidodadi merupakan desa yang sebagian besar penduduknya bekerja sebagai pekerja di industri pembuatan batu bata. Survey awal yang telah dilakukan oleh peneliti menunjukkan bahwa jumlah pesanan batu bata tiap bulan berbeda sedangkan jumlah pekerja yang dilibatkan adalah sama, yaitu 20 orang. Tapi pada kenyataannya waktu penyelesaian untuk setiap pesanan berbeda padahal jumlah pekerja sama, fasilitas produksi yang diguankan juga sama, spesifikasi pekerjaan juga sama, bahkan tiap kilang telah memiliki standar mutu operasional untuk menjaga kualitas batu bata. Berdasrkan hal tersebut dapat dilihat terdapat masalah yang berhubungan dengan produktivitas kerja.

Selain itu hasil survey awal juga menunjukkan bahwa pekerja bagian penjemuran batu bata lebih sering merasa haus, lemas, serta kulit dan bibir kering. Peneliti berasumsi pekerja mengalami kekurangan cairan tubuh akibat aktivitas fisik yang berat dan berada pada lingkungan kerja yang panas.

\section{METODE}

Penelitian ini merupakan penelitian kuantitatif dengan rancangan quasy experimental study. Populasi dalam penelitian ini yaitu seluruh pekerja pembuatan batu bata bagian penjemuran, sampel berjumlah 42 orang yang diambil dari seluruh populasi dengan menggunakan teknik total sampling.

Minuman karbohidrat elektrolit yang diberikan kepada pekerja adalah minuman dalam kemasan yang mengandung $15 \mathrm{gr}$ karbohidrat, $15 \mathrm{gr}$ gula, natrium 5\% (125 mg), kalium 5 $\mathrm{mEq} / \mathrm{L}$, kalsium $1 \mathrm{mEq} / \mathrm{L}$ dalam $250 \mathrm{ml}$. Pemberian minuman karbohidrat elektrolit ini diberikan sebanyak $250 \mathrm{ml}$ sebelum jam bekerja dan $250 \mathrm{ml}$ saat jam istirahat selama seminggu.

Pengukuran produktivitas kerja dilakukan dengan melihat jumlah batu bata yang dapat dijemur oleh setiap pekerja bagian penjemuran selama 1 
(satu) kali proses pembuatan batu bata. Seorang pekerja dapat dikatakan produktif apabila mampu mengangkat batu bata untuk dijemur lebih banyak dibandingkan dengan karyawan lain dalam waktu yang sama. Produktivitas kerja dengan hasil ukur 1 sampai dengan 3.571.

Analisis data secara univariat dan bivariate.

\section{HASIL}

Berdasarkan table 1 menunjukkan rerata produktivitas kerja pada pekerja pembuatan batu bata sebelum pemberian minuman karbohidrat elektrolit adalah 3012,50 dengan standard deviasi 143,145.

Tabel 1. Rerata Produktivitas Kerja Sebelum Pemberian Minuman Karbohidrat Elektrolit

\begin{tabular}{|c|c|c|c|c|}
\hline & Mean & $\mathrm{N}$ & $\begin{array}{c}\text { Std. } \\
\text { Deviation }\end{array}$ & $\begin{array}{l}\text { Std. } \\
\text { Error } \\
\text { Mean }\end{array}$ \\
\hline $\begin{array}{l}\text { Produktivitas kerja } \\
\text { sebelum pemberian } \\
\text { minuman karbohidrat } \\
\text { elektrolit }\end{array}$ & 3012.50 & 42 & 143.145 & 22.088 \\
\hline
\end{tabular}

Rerata produktivitas kerja pada pekerja pembuatan batu bata sesudah pemberian minuman karbohidrat elektrolit adalah 3306,24 dengan standard deviasi 180,804 seperti dijelaskan pada tabel 2 .

Tabel 2. Rerata Produktivitas Kerja Sesudah Pemberian Minuman Karbohidrat Elektrolit

\begin{tabular}{lcccc}
\hline & Mean & N & $\begin{array}{c}\text { Std. } \\
\text { Deviation }\end{array}$ & $\begin{array}{c}\text { Std. } \\
\text { Error } \\
\text { Mean }\end{array}$ \\
\hline $\begin{array}{l}\text { Produktivitas kerja } \\
\begin{array}{l}\text { sesudah pemberian } \\
\text { minuman karbohidrat } \\
\text { elektrolit }\end{array}\end{array}$ & 3306.24 & 42 & 180.804 & 27.899 \\
\hline
\end{tabular}

Tabel 3 menunjukkan bahwa rerata perbedaan produktivitas kerja sebelum dan sesudah pemberian minuman karbohidrat elektrolit adalah 293,738 dengan standar deviasi 82,812.
Berdasarkan hasil uji statistik dengan menggunakan uji paired sample t-test dengan tingkat kepercayaan 95\% ( $a=$ $0,05)$ diperoleh $p$ value $=0,000 \leq 0,05$, artinya ada pengaruh pemberian minuman karbohidrat elektrolit terhadap produktivitas kerja pada pekerja pembuatan batu bata.

Tabel 3. Pengaruh Pemberian Minuman Karbohidrat Elektrolit Terhadap Produktivitas Kerja Pada Pekerja Pembuatan Batu Bata

\begin{tabular}{|c|c|c|c|c|c|c|c|}
\hline & & \multicolumn{3}{|c|}{ Paired Differences } & \multirow[b]{2}{*}{$t$} & \multirow[b]{2}{*}{$d f$} & \multirow[b]{2}{*}{$\begin{array}{c}\text { Sig. } \\
\text { (2-tailed) }\end{array}$} \\
\hline & & Mean & $\begin{array}{c}\text { Std. } \\
\text { Deviation }\end{array}$ & $\begin{array}{c}\text { Std, Error } \\
\text { Mean }\end{array}$ & & & \\
\hline Pair 1 & $\begin{array}{l}\text { Produktivitas kerja } \\
\text { sebelum pemberian } \\
\text { minuman } \\
\text { karbohidrat } \\
\text { elektrolit - } \\
\text { Produktivitas kerja } \\
\text { sesudah pemberian } \\
\text { minuman } \\
\text { karbohidrat } \\
\text { elektrolit }\end{array}$ & -293.738 & 82.812 & 12.778 & -22.988 & 41 & .000 \\
\hline
\end{tabular}

\section{PEMBAHASAN}

Hasil penelitian menunjukkan bahwa rerata produktivitas kerja sebelum pemberian minuman karbohidrat elektrolit adalah 3012,50 dengan standard deviasi 143,145 (Tabel 1). Berdasarkan hasil tersebut maka pekerja belum mampu melaksanakan pekerjaannya secara optimal. Sebuah kilang batu bata rata-rata mampu menghasilkan 25.000 batu bata dalam 1 (satu) kali proses pembuatan batu bata. Bila jumlah pekerja bagian penjemuran sebanyak 7 orang, maka seharusnya seorang pekerja mampu mengangkat batu bata dari tempat pencetakan ke tempat penjemuran dan dari tempat penjemuran ke tempat pembakaran sebanyak \pm 3.571 batu bata. Namun berdasarkan hasil penelitian diperoleh informasi bahwa jumlah batu bata yang dapat diangkat maksimal hanya 3325 batu bata.

Menurut Tarwaka (2004) dalam Wachidah dkk (2019), jika seseorang mengalami tekanan panas karena bekerja di terik matahari. Jika kita 
beraktifitas di lingkungan yang panas maka reaksi tubuh akan mengeluarkan keringat karena terjadi keseimbangan menerima panas dan kehilangan panas dalam tubuh. Keringat mengandung natrium klorida sehingga menghambat transportasi glukosa yang menyebabkan kontraksi pada otot akan menurun sehingga tubuh kelelahan. Secara bersamaan tubuh juga memunculkan respon berupa rasa haus ketika mengetahui cairan tubuh telah berkurang (Sylvia, 2015).

Selain itu, menurut graham dalam Utami (2013), dehidrasi disertai dengan perubahan keseimbangan elektrolit. Pekerja yang bekerja pada suhu lingkungan panas selama 10 hari ratarata kehilangan antara 4.8 - 6 gram natrium yang setara dengan $12-15$ gram garam ( $\mathrm{NaCL}$ ).

Menurut asumsi peneliti, aktivitas fisik pekerja bagian penjemuran yang berat selama pemindahan batu bata dari tempat pencetakan ke tempat penjemuran dan dari tempat penjemuran ke tempat pembakaran menyebabkan pekerja mengalami gangguan keseimbangan cairan tubuh. Selain itu, lingkungan kerja yang panas dan paparan terik matahari langsung juga membuat pekerja lebih banyak berkeringat dan merasa haus. Pekerja menjadi lebih sering beristirahat untuk minum dan mengumpulkan tenaga mereka kembali. Akibatnya produktivitas kerja menjadi menurun, proses pengangkatan batu bata menghabiskan banyak waktu dan proses penjemuran dimulai lebih lama dari target waktu yang telah ditentukan sehingga pada akhirnya tidak bisa selesai dalam 1 hari walaupun cuaca cerah dan lebih dari 5 hari ketika hujan.

Hasil penelitian menunjukkan bahwa rerata produktivitas kerja sesudah pemberian minuman karbohidrat elektrolit adalah 3306,24 dengan standard deviasi 180,804 (Tabel
2). Berdasarkan hasil penelitian juga diperoleh informasi bahwa selama 1 (satu) minggu setelah diberikan minuman terjadi peningkatan produktivitas kerja yang bervariasi namun relatif stabil dari hari ke hari.

Produktivitas kerja pada pekerja pembuatan batu bata bagian penjemuran yang awalnya hanya mampu mengangkat rata-rata 3012,50 batu bata meningkat setelah pemberian minuman karbohidrat elektrolit menjadi rata-rata 3063,45 batu bata pada hari pertama, rata-rata 3117,43 batu bata pada hari kedua, rata-rata 3173,83 batu bata pada hari ketiga, rata-rata 3224,17 batu bata pada hari keempat, rata-rata 3260,17 batu bata pada hari kelima, dan rata-rata 3306,24 batu bata pada hari kelima.

Produktivitas kerja dipengaruhi oleh banyak hal termasuk ketersediaan zat gizi di tubuh pekerja tersebut. Wolgemuth dalam Utami (2013) menyebutkan bahwa bagi seseorang, yang kurang dalam konsumsi zat gizi akan mempengaruhi kondisi kesehatan, aktivitas dan produktivitas kerja.

Pada saat sebelum, sesaat dan sesudahmelakukan aktivitas fisik, tubuh pekerja harus dipastikan mendapatkan asupan cairan dalam jumlah yang cukup. Penggantian cairan tubuh yang hilang pada saat bekerja tidak dapat dilakukan hanya dengan pemberian air minum saja. Orang yang diberi minuman karbohidrat elektrolit kecepatan rehidrasinya paling tinggi sebesar $73 \%$, air putih (65\%) dan diet cola (54\%) karena cairan elektrolit menambah asupan energy dan mengikat $\mathrm{Na}+$ tetap berada di dalam sel (Koswara, 2010).

Menurut asumsi peneliti, minuman karbohidrat elektrolit yang diberikan kepada pekerja sebanyak $250 \mathrm{ml}$ sebelum jam bekerja mampu menggantikan cairan tubuh yang hilang pada saat beraktivitas dirumah sebelum 
berangkat bekerja dan selama dalam perjalanan menuju kilang batu bata. Sementara itu, $250 \mathrm{ml}$ minuman karbohidrat elektrolit yang diberikan pada saat jam istirahat dapat menggantikan cairan yang hilang pada saat bekerja. Setelah diberikan minuman karbohidrat elektrolit, kebutuhan cairan terpenuhi dan pekerja siap untuk bekerja kembali sehingga produktivitas menjadi tinggi.

Namun jika dilihat dari hasil penelitian, pada hari pertama pemberian minuman karbohidrat elektrolit masih terdapat pekerja yang produktivitas kerjanya tidak meningkat, jumlah batu yang dapat diangkat dari tempat pencetakan ke tempat penjemuran dan dari tempat penjemuran ke tempat pembakaran sama dengan jumlah yang dapat diangkat sebelum diberikan minuman karbohidrat elektrolit.

Hal ini diasumsikan terjadi karena pada hari pertama, pekerja masih merasa belum yakin bahwa minuman karbohidrat elektrolit dapat lebih cepat menggantikan cairan tubuh yang hilang dibanding hanya minum air putih biasa saja sehingga pekerja tidak meminumnya sampai habis.

Hasil penelitian menunjukkan bahwa rerata perbedaan produktivitas kerja sebelum dan sesudah pemberian minuman karbohidrat elektrolit adalah 293,738 dengan standar deviasi 82,812.

Minuman karbohidrat elektrollit untuk meningkatkan kebugaran dengan kandungan gula, asam sitrat, dan mineral. Elektrolit yang hilang dari adalah natrium, klorida dan kalium. Secara normal penggantian elektrolit tidak prioritas sehingga penambahan natrium kedalam minuman glukosa mengakibatkan peningkatan glukosa air diserap oleh usus halus. Rehidrasi yang sempurna juga tidak akan terjadi apabila natrium dan cairan yang hilang bersama keringat belum digantikan.
Minuman karbohidrat diberikan untuk menggantikan cairan yang hilang karena keringat dan menggantikan karbohidrat dari cadangan hati dan otot. Hasil penelitian ini sejalan dilakukan oleh Mardiana (2012) dan Hapsari (2013) bahwa pemberian minuman karbohidrat elektrolit dapat memperbaiki status hidrasi dan mengurangi kelelahan pekerja serta meningkatkan jumlah pekerja yang produktif dari $14,28 \%$ menjadi $45,71 \%$.

\section{KESIMPULAN}

Berdasarkan hasil penelitian dan pembahasan dapat diambil kesimpulan bahwa: rerata produktivitas kerja pada pekerja pembuatan batu bata sebelum pemberian minuman karbohidrat elektrolit adalah 3012,50 dan sesudahnya adalah 3306,24. Hasil uji statistik menunjukkan bahwa ada pengaruh pemberian minuman karbohidrat elektrolit terhadap produktivitas kerja pada pekerja pembuatan batu bata.

Pekerja disarankan untuk selalu memperhatikan asupan cairan ke dalam tubuh. Selain dianjurkan minum air putih sebanyak $250 \mathrm{ml}$ atau satu gelas setiap 20-30 menit secara teratur, pekerja yang aktif bekerja pada lingkungan panas sebaiknya mengkonsumsi minuman karbohidrat elektrolit yang dapat menggantikan energi, cairan tubuh dan elektrolit yang hilang selama dan setelah melakukan aktivitas fisik.

\section{DAFTAR PUSTAKA}

Asian Productivity Organization (APO). 2019. APO Productivity Databook 2019. Tokyo: Keio University Press Inc.

Biggs, Chara, Marie Paterson, Eleni Maunder. 2011. Hydration Status of South African Forestry Workers 
Jurnal Kesehatan Masyarakat \& Gizi, e-ISSN: 2655-0849

Vol. 3 No. 2 Edisi November 2020 - April 2021

https://ejournal.medistra.ac.id/index.php/JKG

Received: 15 Januari 2021 :: Accepted: 27 April 2021 :: Published: 30 April 2021

Harvesting Trees in Auntumn and Winter. The Annals of Occupational Hygiene, Volume 55, Nomor 1, Edisi Januari 2011.

Brake DJ, Bates GP. 2013. Fluid Losses and Hydration Status of Industrial Workers Underthermal Stress Working Extended Shift. Diakses tanggal 5 Desember 2019. http://dx.doi.org/10.1136/oem.60. 2.90

Hapsari, Oqi Bintang, Apoina Kartini. 2013. Pengaruh Minuman Karbohidrat Elektrolit Terhadap Produktivitas Kerja. Journal of Nutrition College, Volume 2, Nomor 4, Tahun 2013.

Koswara Sutrisno, 2010. Minuman Karbohidrat elektrolit. Diakses 5 Desember 2019. http://tekpan.unimus.ac.id/wpcontent/uploads/2013/07/MINUMA N-KARBOHIDRAT ELEKTROLIT.pdf

Mardiana, Apoina Kartini, Baju Widjasena. 2012. Pemberian Cairan Karbohidrat Elektrolit, Status Hidrasi dan Kelelahan pada Pekerja Wanita. Media Medika Indonesia, Volume 46, Nomor 1, Tahun 2012.

Sylvia, Price A, Wilson Lorraine M. 2015. Patofisiogi Konsep Klinis ProsesProses Penyakit. Penerbit buku Kedokteran EGC

Utami, Sri Rahayu. 2013. Hubungan Antara Status Gizi dan Tingkat Kebugaran Jasmani dengan Produktivitas Kerja Pada Tenaga Kerja Wanita Unit Spinning 1 Bagian Winding PT. Apac Inti Corpora Bawen. Skripsi. Universitas Negeri Malang

Wachidah, Siti Nur, dkk. 2019. pengaruh Pemberian Air Kelapa Muda Terhadap Kelelahan Nelayan Yang Melaut Siang Hari. Jurnal Kesehatan. Edisi Khusus, No 1, Februari 2019.

Yuniarsih, Tjutju. 2016. Manajemen Sumber Daya Manusia: Teori,
Aplikasi, dan Isu Penelitian. Cetakan kelima. Bandung: Alfabeta. 